10. Lagrange, F.-Atlas d'ophtalmoscopie de guérre. Masson et Cie., Editeurs. Paris, 1918

11. DE LAPERSONNE.--Indication opératoire dans les blessures de guérre orbitooculaires. Bull. de l'Acad. de Méd., No. 1, pp. 41-44, 1915.

12. Marie Pierre et Charles Chatellin.-Revue neurologique. NovembreDécembre, 1915. Bull. de l'A cad. de Méd., No. 24, 1915.

13. OGuchi.-Augenverletzungen in japanischen Heere wahrend des letzten Krieges. Beit. z. Augenheilk., H. 83, 1913.

14. Parsons. - The psychology of traumatic amblyopia following the explosion of shells. Lancet, April 3, 1915.

15. Shimkin, N. I.-(1) Injuries of visual organ in the present war. Vestnik Ophtal., No. 2, February, 1916.

(2) Gunshot injuries of the orbit and its contents. Vestnik Ophtal., No. 4-5, 1916

(3) Concussions of eyes in the war. Vestnik Ophtal., Nos. 6, 7, 8, 9, 1916.

(4) Disturbances of intra cranial visual paths and cortical visual region owing to gunshot injuries of the skull in war. Vracheb. Gaz., No. 2, 1916.

(5) Gunshot injuries of the eye in the world war. Dissertation for the Degree of M.D. Delivered at the University of Kieff. Published at Odessa, 1917. (Ref. Book Notices, Brtt. Jl. Ophthal., p. 620, November, 1926.

16. Uhтноғ, W.-(1) Ueber die Verletzungen des zentralen Sehbahnes u. des Sehzentrum bei Schädel-resp. Hinterhauptschüssen. Ber, d. Ophthal. Gesell., Heidelberg, 1916.

(2) Handbuch d. ärztlichen Erfahrungen im Weltkriege. Klin. Monatsbl. f. Augenheilk., Bd. V, pp. 303-319, 1922.

\title{
A CASE OF LUXATIO BULBI
}

\author{
BY \\ EDWARD C. ZORAB and W. LINDSAY BURNS
}

(MOORFIELDS EYE HOSPITAL)

AMONG the many "black-out" casualties seen nowadays the following case seemed to us worthy of record because of its comparative rarity.

W. F., an A.F.S. fireman, aged 29 years, attended on October 29 at 11 p.m. with a history that he had fallen over in the dark and struck his face on something which he thought was the edge of a biscuit tin three quarters of an hour previously. He had never before had any trouble with his eyes and was not normally subject to exophthalmos. His left eyeball was dislocated anteriorly, and the lids, which were in much spasm, were almost closed behind the eye. The cornea was completely denuded of epithelium, and there was a large conjunctival tear $5 \mathrm{~mm}$. posterior to the limbus from 6 o'clock to 1 o'clock on the nasal side, there was bruising of both lids, and a certain amount of subconjunctival haemorrhage, but none of the muscles, which could be clearly seen, appeared to be ruptured. The eye was almost immobile, but gave little or no pain. The pupil was small and reacted only very faintly to a bright light. 
The fundus could not be seen in detail owing to the corneal abrasion, but it appeared to be very pale in comparison with that of the right eye. The left vision was perception of light only. The right vision was 6/36. A left facial nerve block was given immediately with 4 per cent. novocain at the neck of the mandible, and after a few minutes the spasm of the eyelids relaxed and the globe was able to be replaced. Almost immediately the vision improved, the pupil reaction became brisk, and the colour of the fundus returned to normal. After a few more minutes he could count fingers at two metres, and his ocular movements, though restricted, were all present. There was still some exophthalmos, due presumably to retro-ocular haemorrhage, but the lids closed easily over the globe. The eye was irrigated, atropine drops instilled, and the lids were closed with strapping, and a pad and bandage applied. $\mathrm{He}$ was admitted to hospital.

The following day the lids were bruised and swollen, but the exophthalmos was less marked. Movements were limited in all directions but apart from a little aching there was no pain. The edges of the conjunctival wound were ragged and torn and rather dirty, but the cornea was healing. On the third day his vision was tested and was found to be:-Right eye 6/5 partly with $\frac{-0.25 \mathrm{sph} .}{-2 \cdot 5 \mathrm{cyl} .} \quad$ Left eye $6 / 5$ partly with $\frac{-0.25 \mathrm{sph} \text {. }}{-2.0 \mathrm{cyl} \text {. }}$ 175 175

day the conjunctiva which had gaped rather widely was sutured with a few interrupted sutures. Moderately severe inflammation of Tenon's capsule followed for which he was treated with irrigations, metaphen drops, short wave diathermy, and M. and B. 693. The dosage of the latter was 3 tablets t.d.s. for three days, 2 tablets t.d.s. for three days, 1 tablet t.d.s. for three days. The inflammation of Tenon's capsule slowly subsided, and with it the exophthalmos also. He left hospital after nineteen days with a clear cornea, full movements, and 6/5 vision, with correction in each eye. There are not a great number of cases of luxatio bulbi in the literature, apart from the non-traumatic variety occurring in high myopes and proptosed eyes. Würdemann ${ }^{1}$ describes several cases, but in most of them there was some complication such as fracture of the orbit or rupture of ocular muscles. Cases used to be seen as the result of gouging with the thumb in street brawls many years ago. Von Hippel ${ }^{2}$ reports a somewhat similar case in which the ophthalmic artery was torn, but not the optic nerve. Although the eye was replaced it was quite blind.

Parsons ${ }^{3}$ mentions three different types of luxatio bulbi :-

(a) Occurring in infants during obstructed labour in which forceps are used.

(b) Self inflicted injuries by lunatics. 
(c) Injury by striking the eye on some object, as in the present case.

The chief points of interest are :-

1. The mechanism of the injury, and non-rupture of the ocular muscles.

2. The anaemia of the fundus, presumably due to stretching of the optic nerve and contained artery, and complete recovery of vision after three quarters of an hour's luxation.

3. Comparative lack of pain throughout.

4. Absence of signs in the fundus.

5. Response of the inflammation of Tenon's capsule to M. and B. 693 and diathermy.

We are indebted to $\mathrm{Mr}$. Humphrey Neame for permission to publish the case.

\title{
BIBLIOGRAPHY
}

1. WÜrdemann.- "Injuries of the Eye." Kimpton, U.S.A., 1932.

2. VON HiPPEL.-Deutsche med. Wochenschr., No. 40, 1907.

3. Parsons. - The Pathology of the Eye, Vol. IV, p 1179, 1908.

\section{CYCLODIATHERMYPUNCTURE IN CASES OF GLAUCOMA*}

\author{
BY \\ Prof. Dr. AlFRed Vogt \\ $Z$ ÜRICH, SWITZERLAND
}

IT is now three years since I and my assistants first made use of the C.D.P. (diathermypunctures of the ciliary body) against glaucoma so that I now feel it essential to describe this operation to my colleagues as well as to recommend it to them as a valuable antiglaucoma-operation.

Three years ago when I described the operation for the first time (Schweiz. med. Wochenschr., 1936, p. 593, and Swiss Ophthal. Soc., Geneva, June 4, 1936, published in the Klin. Monatsbl.f. Augenheilk., Vol. C., p. 672) I not only stressed its advantages, but especially pointed out its dangers.

These dangers, which I described fully (Klin. Monatsbl. $f$. Augenheilk., Vol. XCIX., July 9, 1937), we succeeded in reducing and eventually avoiding during these three years, so I believe

- Translated from the German by Mrs. Helen F. Sieger-Bechtler, and Dr. med. G. Gerhart Meyer. 